\title{
Kesejahteraan psikologis, kualitas kehidupan kerja dan keterikatan kerja pegawai BNPP
}

\author{
Rinda Kumala Watia,1, Aulia Aulia ${ }^{b, 2 *}$ \\ aMagister Psikologi Profesi, Fakultas Psikologi, Universitas Gadjah Mada, Yogyakarta \\ bFakultas Psikologi, Universitas Ahmad Dahlan, Yogyakarta \\ 1rindaweka16@gmail.com; *2aulia@psy.uad.ac.id \\ *Correspondent Author
}

Received: 04-08-2021

Revised: 09-08-2021

Accepted: 22-08-2021

\section{KATAKUNCI}

kesejahteraan psikologis; keterikatan kerja;

kualitas kehidupan kerja

\section{KEYWORDS}

psychological well-being; quality of work life; work engagement

\section{ABSTRAK}

Bekerja sebagai pegawai BNPP khususnya sebagai anggota tim SAR yang memiliki pekerjaan berisiko tinggi berpeluang besar membuat pegawai mengalami disengage. Disengage yang dialami pegawai akan berdampak pada burnout, turnover, rendahnya kinerja pribadi bahkan performa organisasi. Dengan demikian, mengetahui faktor yang memiliki hubungan dengan keterikatan kerja merupakan sesuatu yang penting agar dapat meminimalisir terjadinya disengage pegawai BNPP. Oleh karena itu, penelitian ini bertujuan untuk menguji hubungan antara kesejahteraan psikologis dan kualitas kehidupan kerja dengan keterikatan kerja pegawai BNPP. Penelitian ini menggunakan metode kuantitatif dengan pendekatan korelasional. Populasi penelitian ini adalah pegawai BNPP DIY dan Jawa Tengah yang memiliki masa kerja minimal satu tahun. Teknik pengambilan sampel pada penelitian ini menggunakan purposive sampling, yaitu menggunakan pegawai BNPP yang bekerja di bidang Operasi Pencarian Pertolongan dan Kesiapsiagaan atau biasa disebut dengan Tim SAR dari wilayah kerja DIY dan Jawa Tengah dengan total sampel sebanyak 88 orang pegawai. Alat ukur yang digunakan meliputi tiga skala, yaitu UWES modifikasi, skala kesejahteraan psikologis, dan WRQoL. Teknik analisis yang digunakan adalah regresi linear berganda. Hasil analisis menunjukkan perolehan koefisien regresi sebesar $R=0,415$ dengan $p=0,00 \quad(p<0,001)$, artinya terdapat hubungan yang sangat signifikan antara kesejahteraan psikologis dan kualitas kehidupan kerja dengan keterikatan kerja. Selanjutnya, hasil penelitian menunjukan adanya korelasi antara kesejahteraan psikologis dan keterikatan kerja sebesar $r_{x y}=0,285$ dengan $p=0,004$ $(\mathrm{p}<0,001)$. Begitupula adanya korelasi antara kualitas kehidupan kerja dan keterikatan kerja, yaitu sebesar $r_{x y}=0,403$ dan $p=0,000$ $(\mathrm{p}<0,001)$. Penelitian ini menyimpulkan bahwa secara simultan dan parsial bahwa kesejahteraan psikologis dan kualitas kehidupan kerja memiliki hubungan dengan keterikatan kerja pegawai BNPP.

\section{Psychological well-being, quality of work life and work engagement of BNPP employees}

Working as a BNPP employee, especially as a member of the SAR team who has a high-risk job, has a high chance of causing employees to experience disengage. Disengage experienced by employees will have an impact on burnout, turnover, low personal performance and even organizational performance. Thus, knowing the factors that have a 
relationship with work engagement is important in order to minimize the occurrence of disengage by BNPP employees. Therefore, this study aims to examine the relationship between psychological well-being and quality of work life with BNPP employee work engagement. This study uses a quantitative method with a correlational approach. The population of this study were BNPP DIY and Central Java employees who had a minimum of one year of service. The sampling technique in this study used purposive sampling, which used BNPP employees who worked in the field of Rescue and Preparedness Search Operations or commonly referred to as the SAR Team from the DIY and Central Java work areas with a total sample of 88 employees. The measuring instrument used includes three scales, namely the modified UWES, the psychological well-being scale, and the WRQoL. The analysis technique used is multiple linear regression. The results of the analysis show that the regression coefficient is $R=0.415$ with $p=0.00$ ( $p<0.001)$, meaning that there is a very significant relationship between psychological wellbeing and quality of work life with work engagement. Furthermore, the results showed that there was a correlation between psychological wellbeing and work engagement of $r x y=0.285$ with $p=0.004 \quad(p<0.001)$. Likewise, there is a correlation between the quality of work life and work engagement, which is equal to $r x y=0.403$ and $p=0.000(p<0.001)$. This study concludes that simultaneously and partially that psychological well-being and quality of work life have a relationship with BNPP employee work engagement.

This is an open-access article under the CC-BY-SA license.

\section{Pendahuluan}

Berdasarkan peraturan pemerintah dalam Undang-Undang nomor 29 tahun 2016 dan peraturan Presiden Republik Indonesia nomor 83 tahun 2016 tentang Badan Nasional Pencarian dan Pertolongan, pemerintah resmi mengganti nama Badan SAR Nasional (BASARNAS) menjadi Badan Nasional Pencarian dan Pertolongan atau yang selanjutnya dikenal dengan (BNPP). BNPP memiliki tugas membantu Presiden dalam menyelenggarakan urusan pemerintahan, khususnya di bidang pencarian dan pertolongan (search and rescue/SAR). BNPP memiliki tiga bagian dengan fungsi yang berbeda-beda dalam pelaksanaan tugas. Tiga bagian tersebut meliputi Deputi Bidang Sarana dan Prasarana, dan Sistem Komunikasi Pencarian serta Pertolongan; Deputi bidang Tenaga dan Potensi Pencarian dan Pertolongan; dan Deputi Bidang Operasi Pencarian Pertolongan, dan Kesiapsiagaan atau biasa disebut dengan Tim SAR. Tim SAR dalam hal ini adalah tim yang bertugas untuk terjun melakukan operasi lapangan secara langsung ketika ada bencana. Namun pada beberapa kondisi kebencanaan yang membutuhkan banyak tenaga, maka pegawai dari deputi lain memiliki kemungkinan untuk ikut turut terjun dalam tugas. Berdasarkan hal tersebut, seluruh pegawai BNPP diberi keterampilan dan tanggung jawab untuk sewaktu-waktu terjun dalam operasi penyelamatan.

Tingginya beban dan tuntutan kerja dalam menjalankan tugas yang diberikan organisasi tentu membuat pegawai BNPP, khususnya tim SAR harus menempuh risiko yang tinggi berkaitan dengan keselamatan kerja. Salah satu bentuk risiko keselamatan kerja ini tergambar dari beberapa kejadian yang pernah dialami oleh anggota tim SAR, diantaranya meninggal akibat mengalami dekompresi saat evakuasi pesawat Lion Air JT610 di perairan Karawang pada November 2018 (BBC News Indonesia, 2018). Tidak hanya itu, kejadian lain 
yaitu pada tahun 2017 dimana helikopter Tim SAR menabrak tebing dan jatuh pada saat menuju lokasi musibah di kawah Sileri, Dieng, Banjarnegara yang pada akhirnya menyebabkan empat anggota tim SAR meninggal saat bertugas (Detiknews, 2017).

Berbicara mengenai risiko pekerjaan, Bakker dan Leiter (2010) menyampaikan bahwa risiko pekerjaan yang tinggi akan mengakibatkan kelelahan kerja atau burnout yang kemudian menyebabkan menurunnya keterikatan kerja. Keterikatan kerja sendiri adalah kondisi pikiran yang positif, puas dan termotivasi dalam melakukan pekerjaan, dimana hal ini memiliki relasi dengan kesejahteraan dan dapat dilihat sebagai sesuatu yang berlawanan dengan kelelahan kerja atau burnout (Bakker, Schaufeli, Leiter \& Taris, 2008). Selanjutnya, survei yang dilakukan Opin Enterprise Drupal (2012), menjelaskan bahwa ketika karyawan memiliki keterikatan yang rendah atau disebut disengaged maka akan berdampak pada kinerjanya. Adapun dampak dari disengaged yaitu menurunnya semangat kerja, keterlibatan kerja, kualitas kerja, serta kontribusi yang minimal dalam pekerjaannya. Dengan demikian, keterikatan kerja merupakan sebuah komponen penting dalam menunjang kinerja seseorang.

Menurut Schaufeli dan Bakker (2003), keterikatan kerja adalah fikiran dan sikap positif yang dimiliki oleh karyawan dan ditandai dengan adanya vigor, dedication, dan absorbtion. Vigor merujuk pada tingkat energi dan ketahanan mental yang kuat saat bekerja, kemauan untuk berinvestasi, tidak mudah lelah dan kegigihan dalam menghadapi kesulitan apapun dalam pekerjaan. Dedication merupakan perasaan terlibat dalam diri individu secara kuat, bersedia meluangkan banyak waktu dan usaha, mengalami rasa penting, antusiasme, inspirasi, serta bangga dengan pekerjaan yang dijalani. Selain itu, ditandai juga dengan adanya kemauan untuk bekerja keras, presistensi, bahkan tidak mudah lelah dan tekun dalam menghadapi kesulitan. Sementara absroption adalah suatu kondisi dalam diri karyawan yang menunjukkan adanya konsentrasi yang penuh, bahagia dan senang dalam melakukan pekerjaan sehingga waktu terasa berlalu dengan cepat, melupakan segala sesuatu di sekitarnya dan sulit melepaskan diri dari pekerjaan.

Robertson dan Cooper (2010), menjelaskan bahwa kesejahteraan psikologis merupakan salah satu faktor penting yang mempengaruhi keterikatan kerja. Hal tersebut sesuai dengan penelitian Kimberly dan Utoyo (2013) yang menunjukan adanya hubungan positif yang signifikan antara kesejahteraan psikologis dan keterikatan kerja. Artinya, adanya kondisi psikologis yang baik, ketika seseorang menyadari dan dapat memanfaatkan potensi dirinya secara utuh maka akan meningkatkan keterikatan kerja. Ryff dan Keyes (1995) menjelaskan bahwa kesejahteraan psikologis memiliki enam dimensi. Dimensi-dimensi tersebut diantaranya berhubungan dengan penerimaan diri (self-acceptance), hubungan positif dengan orang lain (positive relation with others), pertumbuhan pribadi (personal growth), tujuan hidup (purpose in life), penguasaan lingkungan (environmental mastery), dan otonomi (autonomy). Selanjutnya, Ryff (1995) menjelaskan bahwa karyawan yang memiliki kesejahteraan psikologis yang tinggi ditandai dengan memiliki penerimaan diri, otonomi, hubungan baik dengan orang lain dan penguasaan lingkungan yang baik. Interaksi antara kondisi psikologis yang sehat tersebut akan membuat karyawan merasakan emosi-emosi positif dan pengalaman yang bermakna (Robertson \& Cooper, 2010). Kebahagiaan dalam bentuk suasana hati dan emosi yang menyenangkan serta sikap positif akan menjadikan pengalaman yang baik di tempat kerja, dimana hal tersebut akan menyebabkan tingginya keterikatan kerja (Fisher, 2010).

Selain kesejahteraan psikologis, keterikatan kerja juga dipengaruhi oleh kualitas kehidupan kerja. Kanten dan Sadullah (2012), menjelaskan bahwa kualitas kehidupan kerja berperan membantu karyawan dalam mengelola kehidupan personal mereka yang pada akhirnya dapat meningkatkan keterikatan kerja. Kualitas kehidupan kerja merupakan salah satu tujuan penting dalam memenuhi kebutuhan dan keinginan pekerja (Cascio, 2006). Seperti yang disampaikan Bernardin dan Russel (1993), kualitas kehidupan kerja menjadi penting karena kualitas kehidupan kerja didefinisikan sebagai tingkat dimana individu 
merasa puas dengan kebutuhan penting dirinya. Selanjutnya, menurut Easton dan Van Laar (2012), kualitas kehidupan kerja terdiri dari enam dimensi, diantaranya job an career satisfaction (kepuasan kerja), general well-being (kesejahteraan umum), home-work interface (hubungan antara rumah dan pekerjaan), stress at work (stres kerja), control at work (kontrol kerja), working conditions (kondisi kerja). Kurniawati (2018) menjelaskan bahwa dengan adanya dukungan serta hubungan yang baik di lingkungan kerja merupakan cerminan bahwa lingkungan pekerjaan merupakan lingkungan yang sehat, dan hal tersebut akan memunculkan motivasi dari dalam diri seseorang untuk menaikkan kinerja, begitupula secara otomatis dapat berpengaruh terhadap peningkatan keterikatan kerja.

Berdasarkan pemaparan sebelumnya menunjukan bahwa keterikatan kerja merupakan aspek psikologis yang penting untuk dimiliki oleh pegawai BNPP khsusnya bagi mereka yang terlibat sebagai anggota tim SAR. Hal ini dikarenakan pekerjaan sebagai anggota tim SAR merupakan salah satu pekerjaan yang memiliki risiko tinggi dan berpeluang besar untuk membuat anggota mengalami disengaged dengan pekerjaan yang dilakukan. Selanjutnya, berdasarkan teori dan hasil penelitian sebelumnya menunjukan bahwa kesejahteraan psikologis dan kualitas kehidupan kerja memiliki hubungan dengan keterikatan kerja. Oleh karena itu, mengingat bahwa penelitian yang mengkaitkan ketiga variabel tersebut belum pernah dilakukan dalam lingkup BNPP, maka penelitian ini bertujuan untuk menguji secara empiris hubungan antara kesejahteraan psikologis dan kualitas kehidupan kerja dengan keterikatan kerja pada pegawai BNPP, baik secara simultan ataupun secara parsial. Kajian yang dilakukan pada penelitian ini dalam rangka memberikan kontribusi terhadap bidang psikologi industri dan organisasi, khususnya dalam konteks keterikatan kerja.

\section{Metode}

Metode pada penelitian ini menggunakan metode kuantitatif dengan pendekatan korelasi. Populasi penelitian ini adalah pegawai BNPP DIY dan Jawa Tengah yang memiliki masa kerja minimal satu tahun. Teknik sampling yang digunakan adalah purposive sampling. Dengan demikian sampel pada penelitian ini merupakan pegawai BNPP yang bekerja di bidang Operasi Pencarian Pertolongan, dan Kesiapsiagaan atau biasa disebut dengan Tim SAR dari wilayah kerja DIY dan Jawa Tengah, dengan total sampel sebanyak 88 orang anggota.

Pengukuran variabel pada penelitian ini menggunakan tiga skala. Pengukuran keterikatan kerja pada penelitian ini mengadopsi Utrecht Work Engagement Scale (UWES) dari Schaufeli dan Bakker (2003) yang telah dimodifikasi oleh Aulia, Sutanto dan Hidayat (2018). Pengukuran kesejahteraan psikologis mengadopsi skala kesejahteraan psikologis yang disusun oleh Rohimah (2017). Selanjutnya kualitas kehidupan kerja pada penelitian ini mengadopsi the Work-Related Quality of Life Scale (WRQoL) dari Easton dan Van Laar (2012) yang telah diadaptasi oleh Rahmatya (2018). Koefisien reliabilitas masing-masing alat ukur pada penelitian ini, untuk UWES memiliki koefisien reliabilitas sebesar $r t t=0,898$, skala kesejahteraan psikologis memiliki koefisien reliabilitas sebesar $\mathrm{rtt}=0,908$, dan WRQoL memiliki koefisien reliabilitas sebesar $\mathrm{rtt}=0,915$. Koefisien relibilitas dari ketiga alat ukur tersebut menunjukan bahwa alat ukur reliabel dan dapat digunakan pada penelitian.

Selanjutnya, analisis data yang digunakan pada penelitian ini adalah teknik analisis regresi linier berganda. Tujuannya adalah ingin melihat hubungan secara simultan dari ketiga variabel dan hubungan dari masing-masing varibel bebas dengan variabel tergantung secara parsial. Sebelumnya peneliti melakukan uji asumsi yang terdiri dari uji normalitas, uji linieritas dan uji multikolinieritas.

\section{Hasil}

Hasil uji normalitas pada tabel 1 menunjukan koefisien sebesar KS-Z=0,068 dan p=0,200 $(p>0,05)$. Artinya, varian data penelitian memiliki nilai residual yang berdistribusi normal. 
Tabel 1.

Hasil Uji Normalitas

\begin{tabular}{llll}
\hline Data & KS-Z & Sig $(\boldsymbol{p})$ & Keterangan \\
\hline Unstandardized residual & 0,068 & 0,200 & Normal \\
\hline
\end{tabular}

Hasil uji linieritas berdasarkan tabel 2 memperlihatkan adanya hubungan yang linier antara variabel kesejahteraan psikologis dan keterikatan kerja, dengan taraf signifikansi penyimpangan dari linieritas adalah sebesar $p=0,638(p>0,05)$ dan taraf signifikansi pada linieritas sebesar $\mathrm{p}=0,012(\mathrm{p}<0,05)$. Selanjutnya, hasil uji lineritas pada variabel kualitas kehidupan kerja dan keterikatan kerja menunjukan taraf signifikansi penyimpangan dari linieritas adalah sebesar $p=0,859(p>0,50)$ dan nilai $p$ pada linieritas adalah sebesar $p=0,000$ $(p<0,05)$, sehingga dapat disimpulkan hubungan antara variabel kualitas kehidupan kerja dengan keterikatan kerja juga tergolong linear.

Tabel 2.

Hasil Uji Linearitas

\begin{tabular}{llll}
\hline Variabel & Deviation from linearity $(\boldsymbol{p})$ & Linearity $(\boldsymbol{p})$ & Keterangan \\
\hline $\begin{array}{l}\text { Kesejahteraan psikologis* } \\
\text { keterikatan kerja }\end{array}$ & 0,638 & 0,012 & Linear \\
$\begin{array}{l}\text { Kualitas kehidupan kerja* } \\
\text { keterikatan kerja }\end{array}$ & 0,859 & 0,000 & Linear \\
\hline
\end{tabular}

Berdasarkan hasil uji multikolonieritas pada tabel 3, diketahui variabel kesejahteraan psikologis dan kualitas kehidupan kerja memiliki nilai tolerance sebesar 0,755 $(>0,1)$ dan nilai VIF sebesar $1,325(<10)$. Oleh karena itu dapat disimpulkan bahwa diantara kedua variabel bebas tidak terjadi multikolonieritas.

Tabel 3.

Hasil Uji Multikolonieritas

\begin{tabular}{llll}
\hline Variabel & Tolerance & Nilai VIF & Keterangan \\
\hline $\begin{array}{l}\text { Kesejahteraan psikologis * kualitas } \\
\text { kehidupan kerja }\end{array}$ & 0,755 & 1,325 & $\begin{array}{l}\text { Tidak terjadi } \\
\text { multikolinearitas }\end{array}$ \\
\hline
\end{tabular}

Berdasarkan hasil uji analisis regresi berganda pada tabel 4 menunjukan perolehan koefisien nilai $R$ sebesar $R=0,415$ dengan taraf signifikansi $p=0,000 \quad(0<0,01)$. Hal ini menunjukkan bahwa secara simultan terdapat hubungan yang sangat signifikan antara kesejahteraan psikologis dan kualitas kehidupan kerja dengan keterikatan kerja pegawai BNPP. Kesejahteraan psikologis dan kualitas kehidupan kerja memberikan sumbangan efektif sebesar $17,2 \%$ terhadap keterikatan kerja.

Tabel 4.

Regresi Linier Berganda

\begin{tabular}{llll}
\hline $\boldsymbol{R}$ & $\boldsymbol{R}$ Square & $\boldsymbol{p}$ & Keterangan \\
\hline 0,415 & 0,172 & 0,000 & Sangat signifikan \\
\hline
\end{tabular}

Analisis berikutnya dilanjutkan dengan pengujian antara masing-masing variabel seperti yang terlihat pada tabel 5 . Berdasarkan hasil korelasi antara variabel kesejahteraan psikologis dan keterikatan kerja $\left(r_{x 1 y}\right)$ adalah sebesar 0,285 dengan taraf signifikansi $p=0,004$ $(\mathrm{p}<0,01)$. Hasil analisis menunjukan adanya hubungan positif yang sangat signifikan antara 
kesejahteraan psikologis dan keterikatan kerja pegawai BNPP. Selanjutnya nilai positif dari korelasi menunjukan bahwa semakin tinggi kesejahteraan psikologis maka akan semakin tinggi pula keterikatan kerja pegawai BNPP. Sebaliknya, semakin rendah kesejahteraan psikologis maka akan semakin rendah pula keterikatan kerja pegawai BNPP. Hasil penelitian juga menunjukan sumbangan efektif dari kesejahteraan psikologis terhadap keterikatan kerja adalah sebesar $3,22 \%$.

Berikutnya, hasil analisis korelasi antara variabel kualitas kehidupan kerja dan keterikatan kerja $\left(\mathrm{r}_{\mathrm{x} 2 \mathrm{y}}\right)$ adalah sebesar 0,403 dengan taraf signifikansi 0,000 $(\mathrm{p}<0,01)$. Hasil analisis menunjukan adanya hubungan positif yang sangat signifikan antara kualitas kehidupan kerja dan keterikatan kerja pegawai BNPP. Selanjutnya, nilai positif dari korelasi menunjukan bahwa semakin tinggi kualitas kehidupan kerja maka akan semakin tinggi pula keterikatan kerja pegawai BNPP. Sebaliknya semakin rendah kualitas kehidupan kerja maka akan semakin rendah pula keterikatan kerja pegawai BNPP. Hasil penelitian juga menunjukan sumbangan efektif dari kualitas kehidupan kerja terhadap keterikatan kerja adalah sebesar $13,86 \%$.

Tabel 5.

Hasil Uji Korelasi

\begin{tabular}{lllll}
\hline Variabel & $\boldsymbol{r x y}$ & $\boldsymbol{S E}$ & $\boldsymbol{p}$ & Keterangan \\
\hline Kesejahteraan psikologis*keterikatan kerja & 0,285 & $3,22 \%$ & 0,004 & Sangat signifikan \\
Kualitas kehidupan kerja*keterikatan kerja & 0,403 & $13,86 \%$ & 0,000 & Sangat signifikan \\
\hline
\end{tabular}

\section{Pembahasan}

Hasil penelitian menunjukkan bahwa kesejahteraan psikologis dan kualitas kehidupan kerja secara simultan memiliki hubungan dengan keterikatan kerja. Pada penelitian ini, sumbangan efektif dari kesejahteraan psikologis dan kualitas kehidupan kerja secara bersama-sama terhadap keterikatan kerja adalah sebesar 17,2\%. Artinya, masih ada sebesar $82,8 \%$ sumbangan efektif dari variabel lain yang tidak dibahas pada penelitian ini.

Selanjutnya, berdasarkan hasil analisis korelasi menunjukkan adanya hubungan positif yang sangat signifikan antara kesejahteraan psikologis dan keterikatan kerja. Sumbangan efektif dari variabel kesejahteraan psikologis terhadap keterikatan kerja adalah sebesar 3,22\%. Hasil penelitian ini sesuai dengan penelitian Sahin dan Cankir (2018) yang menjelaskan kesejahteraan psikologis sebagai prediktor dari keterikatan kerja. Namun demikian, hasil penelitian ini menunjukkan adanya perbedaan dengan penelitian Indrianti (2012) yang menyatakan bahwa tidak ada korelasi antara modal psikologis dengan keterikatan kerja yang dilakukan pada perawat di instansi Rawat inap Rumah Sakit Jiwa Menur Surabaya, dimana kesejahteraan psikologis adalah bagian dari modal psikologis. Sebaliknya, hasil penelitian ini didukung oleh hasil penelitian Simanullang dan Ratnaningsih (2018) yang dilakukan pada subjek perawat pada instalasi rawat inap di Rumah Sakit Kota Semarang.

Berdasarkan hasil penelitian dapat dijelaskan bahwa tinggi ataupun rendahnya keterikatan kerja pegawai BNPP turut dipengaruhi oleh tinggi ataupun rendahnya kesejahteraan psikologis pegawai. Artinya, semakin tinggi kesejahteraan psikologis maka semakin tinggi pula keterikatan kerja pegawai BNPP. Sebaliknya, semakin rendahnya kesejahteraan psikologis akan diikuti dengan rendahnya keterikatan kerja pada pegawai BNPP. Pegawai BNPP dengan kesejahteraan psikologis yang tinggi akan memiliki kemampuan mengevaluasi atau menilai kemampuannya untuk mengenali potensi yang ada pada dirinya dan kemudian akan mengoptimalkan potensi tersebut dalam berbagai aspek kehidupan, terutama ketika menghadapi berbagai macam tantangan dan perubahan dalam pekerjaan ataupun hidupnya. Hal ini sesuai dengan penelitian Simanullang dan Ratnaningsih (2018) yang menjelaskan bahwa kondisi kesejahteraan psikologis yang baik membuat 
perawat di rumah sakit menyadari potensi dirinya secara utuh dan memiliki emosi positif sehingga meningkatkan keterikatan kerja. Sebaliknya, emosi negatif dapat menyebabkan menurunnya keterikatan kerja.

Berikutnya, hasil penelitian menunjukan adanya hubungan antara kualitas kehidupan kerja dan keterikatan kerja. Kualitas kehidupan kerja memberikan sumbangan efektif sebesar $13,86 \%$ terhadap keterikatan kerja. Hasil penelitian ini didukung oleh penelitian yang dilakukan oleh Rahmayuni dan Ratnaningsih (2018) yang menunjukkan adanya korelasi antara kualitas kehidupan kerja dengan keterikatan kerja. Selanjutnya, hasil penelitian ini mendukung penelitian Nurendra dan Purnamasari (2017) yang menjelaskan bahwa ada hubungan positif antara kualitas kehidupan kerja dan keterikatan kerja pada pekerja wanita.

Berdasarkan hasil penelitian memperlihatkan bahwa tinggi ataupun rendahnya keterikatan kerja pegawai BNPP dipengaruhi oleh tinggi ataupun rendahnya kualitas kehidupan kerja pegawai. Artinya, semakin tinggi kualitas kehidupan kerja maka semakin tinggi keterikatan kerja pegawai BNPP. Sebaliknya, semakin rendahnya kualitas kehidupan kerja maka semakin rendah pula keterikatan kerja anggot BNPP. Pegawai BNPP yang memiliki kualitas kehidupan kerja yang tinggi akan memiliki rasa puas, motivasi, keterlibatan, pengalaman, komitmen dan kepedulian terhadap pekerjaan ataupun tempat kerja, dan untuk selanjutnya akan mempengaruhi keterikatan kerja mereka sebagai pegawai. Hal ini selaras dengan yang disampaikan Rahmayuni dan Ratnaningsih (2018) bahwa dengan terpenuhinya kebutuhan masing-masing individu maka akan membuat karyawan mampu menggunakan potensi yang dimiliki dengan maksimal. Begitupula menurut Kanten dan Sadullah (2012) bahwa penempatan sumber daya manusia sebagai individu yang bertanggungjawab dan mampu memberikan kontribusi yang bernilai secara penuh terhadap pekerjaannya menyebabkan karyawan merasa puas untuk mencurahkan seluruh kemampuan terbaiknya dalam bekerja yang kemudian disebut dengan keterikatan kerja.

\section{Simpulan}

Berdasarkan hasil penelitian dapat disimpulkan bahwa kesejahteraan psikologis dan kualitas kehidupan kerja memiliki hubungan dengan keterikatan kerja pegawai BNPP. Selanjutnya, kesejahteraan psikologis memiliki hubungan positif yang sangat signifikan dengan keterikatan kerja. Hal tersebut berarti bahwa semakin tinggi kesejahteraan psikologis pegawai BNPP, maka akan semakin tinggi pula keterikatan kerja pegawai. Sebaliknya, semakin rendah kesejahteraan psikologis pegawai BNPP, maka akan semakin rendah pula keterikatan kerja pegawai. Hasil penelitian juga menyimpulkan bahwa ada hubungan positif yang sangat signifikan antara kualitas kehidupan kerja dengan keterikatan kerja. Hal tersebut berarti, semakin tinggi kualitas kehidupan kerja pegawai BNPP, maka akan semakin tinggi pula keterikatan kerja pegawai. Sebaliknya, semakin rendah kualitas kehidupan kerja pegawai BNPP, maka akan semakin rendah pula keterikatan kerja pegawai.

\section{DAFTAR PUSTAKA}

Aulia, A., Sutanto, A., \& Hidayat, A. C. (2019). Determinants of work engagement for TNI-AD (Indonesian Armed Forces-Army) personnel [Determinan keterikatan kerja personel Tentara Nasional Indonesia-Angkatan Darat (TNI-AD)].ANIMA Indonesian Psychological Journal, 35(1), 35-55. https://doi.org/10.24123/aipj.v35i1.2881.

Bakker, A.B., \& Leiter, M.P. (2010). Work engagement: A handbook of essential theory and research. New York: Psychology Press.

Bakker, A. B., Schaufeli, W. B., Leiter, M. P., \& Taris, T. W. (2008). Work engagement: An emerging concept in occupational health psychology. Work \& Stress, 22(3), 187-200. https://doi: 10.1080/02678370802393649. 
BBC News Indonesia. (2018 November). Lion Air JT610: Seorang penyelam meninggal saat proses evakuasi. https://www.bbc.com/indonesia/indonesia-46081626.

Bernardin John, H., \& Russel Joyce, E. A. (1993). Human recources management an experiental approach. Singapura. Mc Grae-hill.

Şahin, S. \& Çankır, B., (2018). Psychological well-being and job performance: the mediating role of work engagement. Hitit University Journal of Social Sciences Institute, 11(3), $2549-2560$.

Cascio, W. F. (2006). The economic impact of employee behaviors on organizational performance. In America at work (pp. 241-256). Palgrave Macmillan, New York. https://doi.org/10.1057/9781403983596_14.

Detiknews. (2017, Juli). Tim Basarnas korban heli jatuh dinaikkan status pegawainya. https://news.detik.com/berita/d-3546378/tim-basarnas-korban-heli-jatuh-dinaikkanstatus-pegawainya.

Easton, S., \& Van Laar, D. L. (2012). User manual of the work-related quality of life scale (WRQoL). UK: Portsmouth: University of Portsmout.

Fisher, C. D. (2010). Happiness at work. International Journal of Management Reviews, 12(4), 384-412. https://doi.org/10.1111/j.1468-2370.2009.00270.x.

Indrianti, R. (2012). Hubungan antara modal psikologis dengan keterikatan kerja pada perawat di Instalasi rawat inap Rumah Sakit Jiwa Menur Surabaya. Jurnal Psikologi Industri dan Organisasi, 1(2), 110-116.

Kanten, S., \& Sadullah, O. (2012). An empirical research on relationship quality of work life and work engagement, Procedial-Social and Behavioral Sciences, 62(1), 360-366. https: //doi.org/10.1016/j.sbspro.2012.09.057.

Kimberly \& Utoyo, S. D. B. (2013). Hubungan psychological well-being dan work engagement pada karyawan yang bekerja di lokasi tambang. Paper dipresentasikan di Fakultas Psikologi, Universitas Indonesia.

Kurniawati, C.E. (2018). Pengaruh quality of work life terhadap work engagement dan organizational citizenship behaviour pada Perusahaan Elektronik di Surabaya. Journal Agora, 6(2), 1-10.

Nurendra, A. M., \& Purnamasari, W. (2017). Hubungan antara kualitas kehidupan kerja dan keterikatan kerja pada pekerja wanita. Indigenous: Jurnal Ilmiah Psikologi,2(2), 148154. https://doi.org/10.23917/indigenous.v2i2.5649.

Opin Enterprise Drupal. (2012). Engage vs disenageged employee. https://www.opin. ca/en/article/engaged-vs-disengaged-employees. Diakses pada tanggal 6 Oktober 2018.

Peraturan pemerintah nomor 29 tahun 2016 tentang perubahan modal dasar perseroan terbatas. LN. 2016 No. 137, TLN No. 5901, LL SETNEG: 3 HLM.

Peraturan Presiden RI nomor 83 tahun 2016, pasal 2 tentang Badan Nasional Pencarian dan Pertolongan. 2016. Jakarta: Sekertariat Negara.

Robertson, I. T. \& Cooper, C. L. (2010). Full engagement: the integration of employe engagement and psychological well-being. Leadership and Organization Development Journal, 31, 324-336. https://doi.org/10.1108/01437731011043348

Rohimah, S. (2017). Hubungan antara psychological well-being dengan work engagement pada karyawan PT. Bangunan Jaya Mandiri Yogyakarta. (Skripsi tidak diterbitkan). Universitas Ahmad Dahlan: Yogyakarta.

Rahmatya, N. (2018). Hubungan antara quality of work life dengan work engagement pada petugas pemadam kebakaran Yogyakarta. (Skripsi tidak diterbitkan). Fakultas Psikologi Universitas Ahmad Dahlan: Yogyakarta.

Rahmayuni, T. D., \& Ratnaningsih, I. Z. (2018). Hubungan antara kualitas kehidupan kerja dengan keterikatan kerja pada wartawan TV X Jakarta. Jurnal Empati, 7(1), 373-380.

Ryff, C. D. (1995). Psychological well-being in adult life. Current directions in psychological science, 4(4), 99-104. https://doi.org/10.1111/1467-8721.ep10772395. 
Ryff, C. D., \& Keyes, C. L. M. (1995). The structure of psychological well-being revisited. Journal of Personality and Social Psychology, 69(4), 719-727. https://doi.org/10.1037/0022-3514.69.4.719.

Schaufeli, W. B., \& Bakker, A. B. (2003). Utrecht work engagement scale: Preliminary manual. Department of Psychology. The Netherlands: Utrecht University.

Simanullang, R. T. W., \& Ratnaningsih, I. Z. (2019). Hubungan antara kesejahteraan psikologis dengan keterikatan kerja pada perawat instalasi rawat inap di Rumah Sakit X Kota Semarang. Jurnal EMPATI, 7(4), 1448-1450. 